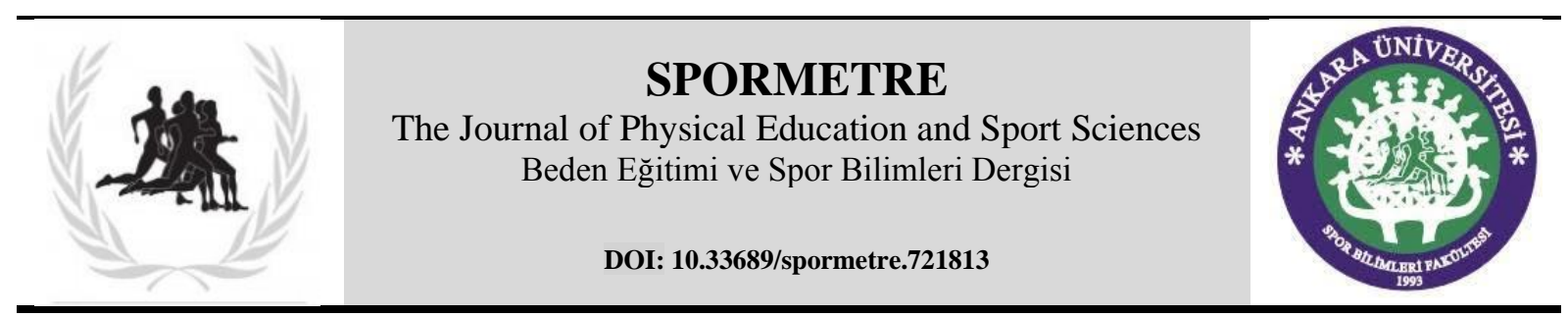

Geliş Tarihi (Received): 17.04.2020 $\quad$ Kabul Tarihi (Accepted): 16.05.2020 $\quad$ Online Yayın Tarihi (published): 19.05.2020

INTERNATIONAL SUCCESSES OF TURKISH JUDO: A HISTORICAL PERSPECTIVE

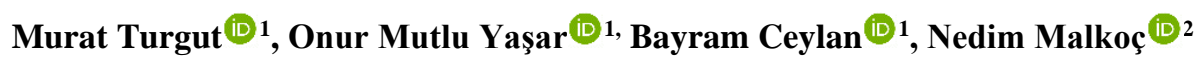 \\ ${ }^{1}$ Kastamonu Üniversitesi, Beden Eğitimi ve Spor Yüksekokulu, KASTAMONU \\ ${ }^{2}$ Sağllk Bilimleri Üniversitesi, Yaşam Bilimleri Fakültesi, İSTANBUL
}

\begin{abstract}
Judo is an Olympic sport which is very popular worldwide. Turkish judo has developed in the recent decades and many successes have been achieved by Turkish judo athletes. However, no study has investigated the successes of Turkish judo. The aim of this study was to present successes of Turkish judo in senior category in the Olympic Games, World Championships and European Championships. This descriptive study was a research about the development of elite sport of judo in Turkey. Results were grouped and analysed according to the decade of success. Data were collected from several official judo websites. At the end of 2019, Turkish judo athletes has taken 51 medals (two in the Olympic Games, 10 in the World Championships, 39 in the European Championships). The number of the medals was highest in the 1990s and 2010s. Men athletes contributed to the medal numbers more than women athletes as the percentage of medals achieved by men athletes was $66 \%$ of the total medals. Turkish judo started to gain a place on the podium at international level in the 1990s but have not been able to reach that success again for the last two decades.
\end{abstract}

Anahtar Kelimeler: Başarı, Mücadele Sporları, Judo, Türkiye

\title{
TÜRK JUDOSUNUN ULUSLARARASI BAŞARILARI: TARİHSEL BİR BAKIŞ
}

Öz: Judo, Dünya çapında popüler olan bir Olimpik spordur. Judo sporu Türkiye'de son yıllarda gelişmiştir ve Türk judo sporcuları birçok başarı elde etmiştir. Ancak literatürde Türk judosunun başarıları üzerinde araştırma yapılmadığı görülmektedir. Bu çalışmanın amacı Olimpiyat Oyunları, Dünya Şampiyonası ve Avrupa Şampiyonasında üst düzey kategoride Türk judo sporcularının başarılarını ortaya koymaktır. Tanımlayıcı tipteki bu çalışma, Türkiye'de judonun seçkin sporunun gelişimi üzerine bir araştırmadır. Sonuçlar onar yıl kapsamında gruplanmış ve analiz edilmiştir. Veriler ulusal ve uluslararası resmi judo web sitesinden elde edilmiştir. 2019 sonunda Türk judo sporcuları 51 madalya almıştır (İkisi Olimpiyat Oyunlarında, 10'u Dünya Şampiyonasında, 39'u Avrupa Şampiyonasında). Türkiye'nin judo sporundaki Madalya sayısı 1990'larda ve 2010'larda en yüksek seviyeye ulaştı. Bunun yanı sıra 1980'lerde madalya sayısı çok azdı. Erkek sporcular Türkiye'nin madalya sayılarına kadın sporculardan daha fazla katkıda bulundular, erkek sporcular tarafından elde edilen madalya yüzdesi toplam madalyanın\%66'sıdır. Türk judosu 1990 'larda uluslararası düzeyde podyumda yer almaya başlamış ve büyük başarılar elde etmiştir ancak son yirmi yılda aynı başarıyı yakalayamamıştır.

Key Words: Combat Sports, Judo, Success, Turkish

\section{INTRODUCTON}

Judo is an Olympic grappling sport that emerged from various traditions of Japanese martial arts. Some scholars claimed that many traditional martial arts in the East Asia conduced to the development of judo when Japan was ruled by the shoguns of the of Tokugawa family. Then it evolved to budo (martial way of life) or jujitsu (technique of pliancy). Later, Jigoro Kano opened the first training hall, Kodokan and suggested a new style of jujitsu 'judo' that was defined as the way of gentleness or giving way by Kano (Sato, 2013). Afterwards, Kano travelled around the world to promote judo as a global sport. In the early 1950s, judo arrived in Turkey and it started its official activities as a federation within the Wrestling Federation in 
1962 (TJF, 2019). During the first years of judo, advanced techniques were unknown and judo was more self-developed sport within the person of skill. Judo has showed significant developments in the country and made a name for itself in the international arena with great moves (IJF, 2019).

Judo became an Olympic sport for the first time in 1964 Tokyo Olympic Games (Little, 1991). In 1966 Judo became an independent federation in Turkey. Right after the establishment and assignment of the first president of the Judo Federation the first national championship and organized in 1967.

Federation carried out its activities as Judo and Taekwondo between the years 1969-1979, Judo and Karate Federation between 1980-1990, since 1990 it has served under the name of the Judo Federation. The presidents of the Federation, who were appointed by appointment until its establishment in 1993, started to work by election according to the regulations issued on that date and in the first elections Nat1k Canca became the President of Judo Federation. Since 1997, Wuhsu, Aikido and Kurash were placed under the Judo Federation. Wushu and Aikido were separated in 2006 and Judo Federation continued its activities as Judo and Kurash Federation until 2011. Finally, in 2011 Kurash was separated from the body, from this date it has continued to pursue its activities in Turkey as Judo Federation (TJF, 2019).

Judo sport with these developments showed significant improvements in Turkey. According to Federation data on the Turkey, there are a total of 111.160 licensed judo athletes, including 72,984 male judo athletes and 38,212 female athletes (TJF, 2019). Despite its popularity in Turkey and recognition in the international platform, no data is available about its international successes since its foundation. Thus, the aim of the present study was to collect and analyze the successes of Turkish judo (senior category) in the Olympic Games, World and European Championships.

\section{MATERIAL AND METHOD}

This descriptive study was a research about the development of judo in Turkey. Turkish Judo Federation has attended the Olympic Games since 1976. The data was obtained from different databases (www.judobase.org, www.judoinside.com, and official websites of International Judo Federation and Turkish Judo Federation). Because the data were provided from open access website and athletes' personal information was not used, there are no ethical issues in analyzing or interpreting these data (Morley \& Thomas, 2005). Olympic Games, World and European Championships successes that Turkey have taken were identified. These results were then grouped and analyzed according to the decade of success.

\section{RESULTS}

Turkish judo has 2 medals at Olympic Games (one gold and one bronze), 10 medals at World Championships (two silver and three eight bronze), thirty-nine medals at European Championship (nine gold, four silver and twenty-six bronze). $66 \%$ of the medals were taken by men athletes while $34 \%$ of the medals were taken by women athletes. Figure 1 presents medal distribution according to decades. 
Figure 1. Medal distribution according to decades.

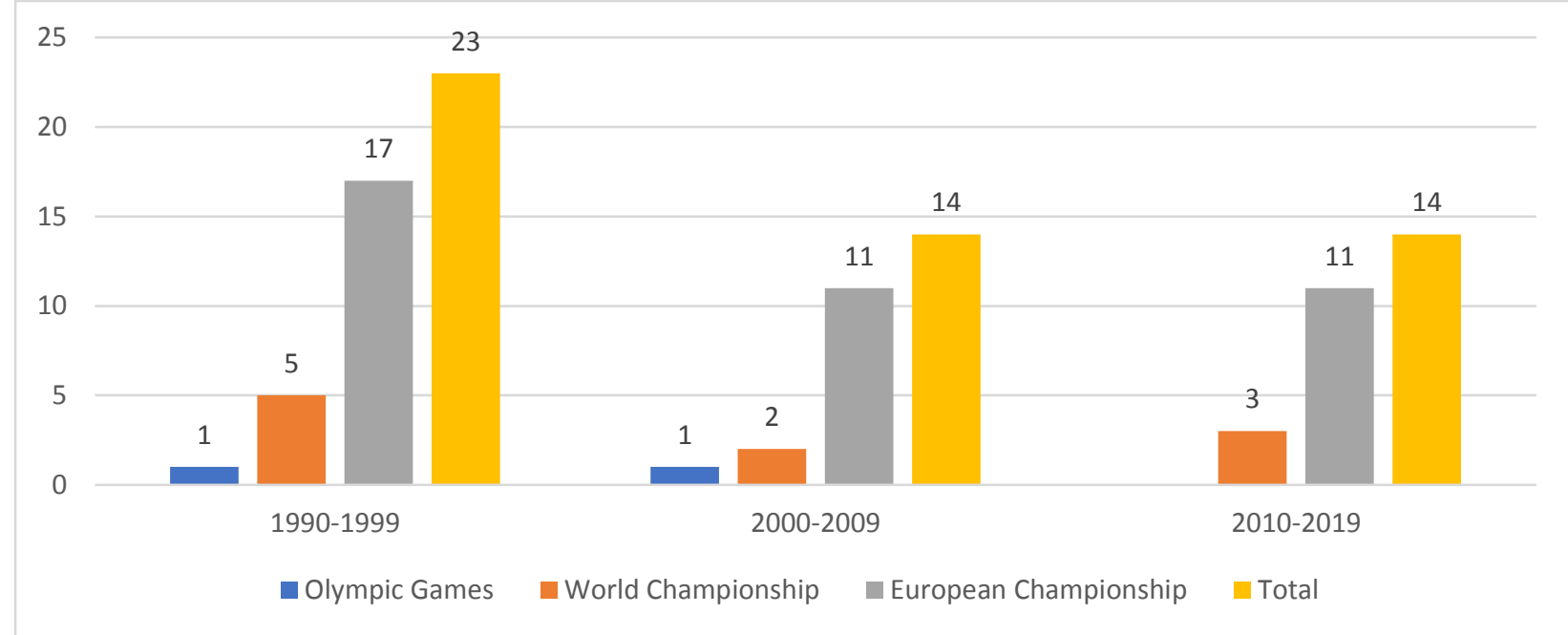

Gender-based information related to medal numbers can be found in Figure 2. For all competitions, men athletes have been dominant in medal numbers when medal numbers are compared according to gender. Turkish judo has one medal in the Olympic Games for each gender in different decades.

Figure 2. Medal numbers of men and women athletes according to decades and competition

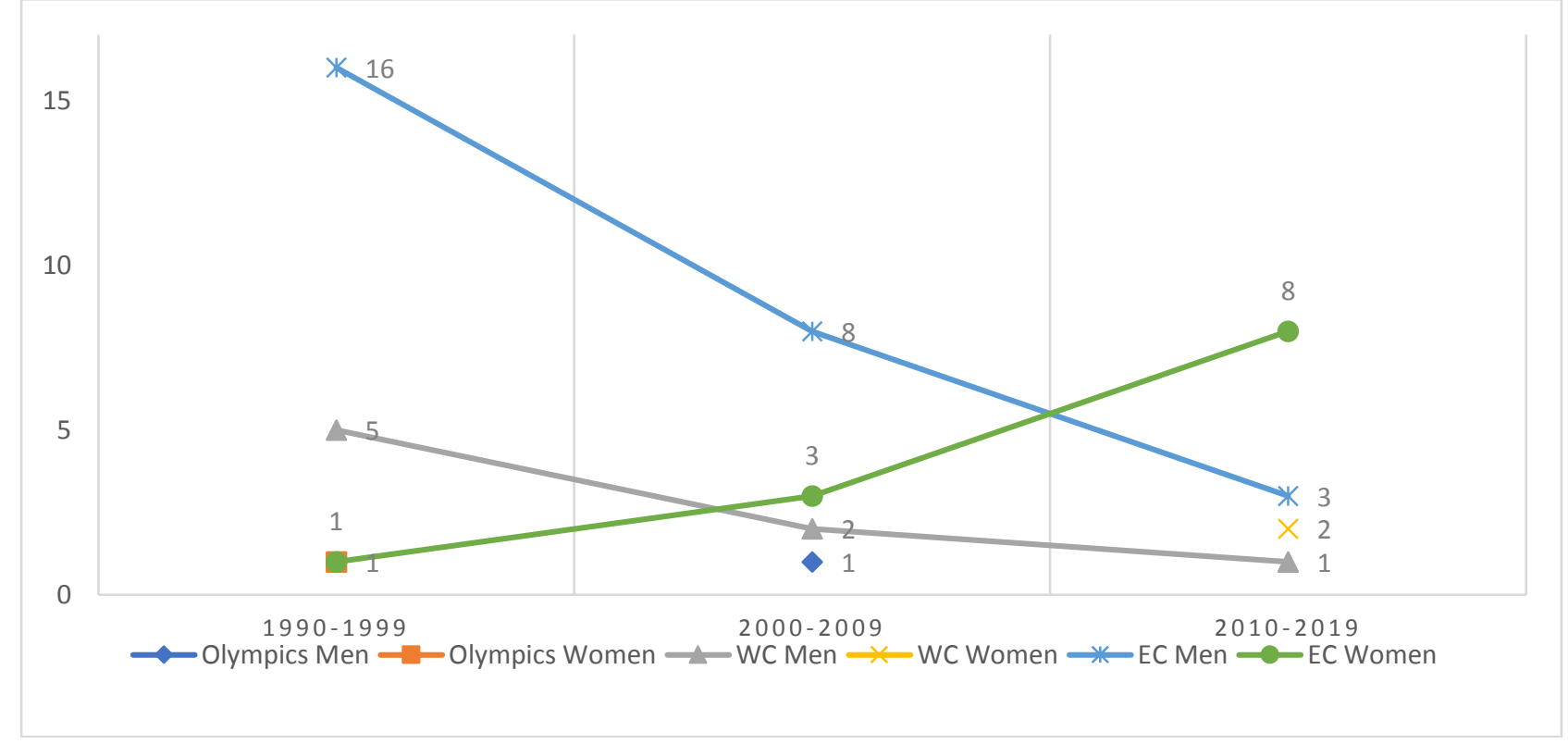

Table 1 presents Olympic medals of Turkish judo. Information related to medals in the World Championships can be found in Table 2. Table 3 presents medals achieved in the European Championships.

Table 1. Olympic medals of Turkish judo

\begin{tabular}{cccc}
\hline Year & Country & Medal & Weight category \\
\hline 1992 & Spain & Silver & U48 (female-originally Turkish) \\
2000 & Australia & Gold & U66 (male-adopted) \\
\hline
\end{tabular}


Table 2. World medals of Turkish judo

\begin{tabular}{lccc}
\hline Year & Country & Medal & Weight category \\
\hline 1995 & Japan & Bronze & U65 (male-adopted) \\
1995 & Japan & Bronze & OPEN (male-adopted) \\
1999 & Great Britain & Silver & U66 (male-adopted) \\
1999 & Great Britain & Silver & OPEN (male-adopted) \\
1999 & Great Britain & Bronze & O100 (male-adopted) \\
2001 & Germany & Bronze & O100 (male-adopted) \\
2003 & Japan & Bronze & U48 (female-originally Turkish) \\
2018 & Azerbaijan & Bronze & O78 (female-adopted) \\
2018 & Azerbaijan & Bronze & U81 (male-adopted) \\
2019 & Japan & Bronze & O78 (female-adopted) \\
\hline
\end{tabular}

Table 3. European medals of Turkish judo

\begin{tabular}{|c|c|c|c|}
\hline Year & Country & Medal & Weight category \\
\hline 1993 & Greece & Bronze & U48 (female-originally Turkish) \\
\hline 1994 & Poland & Bronze & U65 (male-adopted) \\
\hline 1994 & Poland & Bronze & O95 (male-adopted) \\
\hline 1995 & Great Britain & Bronze & U65 (male-adopted) \\
\hline 1995 & Great Britain & Bronze & U78 (male-adopted) \\
\hline 1996 & Netherlands & Bronze & O95 (male-adopted) \\
\hline 1996 & Netherlands & Silver & OPEN (male-adopted) \\
\hline 1997 & Belgium & Gold & U66 (male-adopted) \\
\hline 1997 & Belgium & Gold & O100 (male-adopted) \\
\hline 1997 & Belgium & Bronze & OPEN (male-adopted) \\
\hline 1998 & Spain & Gold & O100 (male-adopted) \\
\hline 1998 & Spain & Bronze & U66 (male-adopted) \\
\hline 1998 & Spain & Bronze & U81 (male-adopted) \\
\hline 1998 & Spain & Bronze & OPEN (male-adopted) \\
\hline 1999 & Slovakia & Gold & OPEN (male-adopted) \\
\hline 1999 & Slovakia & Bronze & U66 (male-adopted) \\
\hline 1999 & Slovakia & Bronze & O100 (male-adopted) \\
\hline 2000 & Poland & Silver & OPEN (male-adopted) \\
\hline 2001 & France & Bronze & U81 (male-adopted) \\
\hline 2001 & France & Bronze & O100 (male-adopted) \\
\hline 2002 & Slovenia & Gold & U81 (male-adopted) \\
\hline 2003 & Netherlands & Bronze & U66 (male-adopted) \\
\hline 2003 & Netherlands & Bronze & U90 (male-originally Turkish) \\
\hline 2004 & Romania & Gold & U66 (male-adopted) \\
\hline 2004 & Romania & Gold & O100 (male-adopted) \\
\hline 2005 & Netherlands & Bronze & U48 (female-originally Turkish) \\
\hline 2006 & Finland & Silver & U48 (female-originally Turkish) \\
\hline 2009 & Georgia & Bronze & O78 (female-originally Turkish) \\
\hline 2011 & Turkey & Bronze & U73 (male-originally Turkish) \\
\hline 2012 & Russia & Bronze & O78 (female-originally Turkish) \\
\hline 2013 & Hungary & Bronze & U48 (female-originally Turkish) \\
\hline
\end{tabular}




\begin{tabular}{lccc} 
& \multicolumn{2}{c}{ Table 3. European medals of Turkish judo (Continued) } \\
2013 & Hungary & Bronze & O78 (female-originally Turkish) \\
2015 & Azerbaijan & Silver & U48 (female-originally Turkish) \\
2015 & Azerbaijan & Bronze & O78 (female-originally Turkish) \\
2016 & Russia & Gold & O78 (female-adopted) \\
2016 & Russia & Bronze & U48 (female-originally Turkish) \\
2016 & Russia & Bronze & O78 (female-originally Turkish) \\
2018 & Israel & Bronze & U73 (male-originally Turkish) \\
2019 & Belarus & Gold & U90 (male-adopted)
\end{tabular}

\section{DISCUSSION}

The success of Turkish judo began in 1990s with medals achieved in the World and European championships in 1990s. The highest number of the medals was achieved during 1990s as indicated in Figure 1. First medal in the Olympic Games was also achieved in 1990s and the second and last Olympic medal was achieved in the 2000s. Since then, no medal has been achieved in the Olympic Games. Medals in the European Championships have been maintained since 1990s but the number has decreased significantly. In the World Championship, the highest number of medals was achieved in the 1990s but it has decreased since then.

Golden age of Turkish judo was 1990s with 5 World and 17 European medals and beginning of 2000s with a gold in the Olympic Games. This was due to the adopted athletes (information was provided from an expert judoka with 20 years of judo experience) as all medals at World and European Championships were achieved by adopted athletes in the 1990s. Even in the 2000 Sydney Olympics the gold medal was achieved by an adopted judo athlete. It can be inferred that the difference between genders resulted from the above-mentioned situation as almost all of the adopted judokas were men. Furthermore, in women category Turkish judo has only two World medals which were achieved by again an adopted judoka. However, the bronze medal at 1992 Olympics was achieved by a woman athlete. In short, Turkish judo has gained totally 51 medals at the Olympics, World and European Championships, 16 of which were achieved by originally Turkish athletes while 35 of which were achieved by adopted athletes. However, young generation of Turkish judo is up-and-coming as cadet team of Turkey gained championships in the European Team Championship and European Team Youth Olympic Festival and third place in the World Team Championship in 2019.

Compared to well developed countries in judo such as Japan, Russia and France Turkish judo has a long way to have a place on the podium in senior category in the Olympics and this can be succeeded with the young generation. As for the most successful countries in the Olympics judo history, Japan is leading with a total of 84 medals, which is inevitable result with 3.500 .000 officially licensed athletes and 5.000 judo clubs (Japan Judo Federation 2020). Japan is followed by France (total medal at the Olympics $=49$ ) with 1.534 .808 licensed athletes (French Judo Federation 2020) and 5.700 clubs and Russia (total medal at the Olympics=41) with 2.500.000 athletes and 2.800 clubs (Russian Judo Federation 2020). They obviously outnumbered Turkish judo in terms of success as the current numbers say that Turkish Judo Federation has 111.160 licensed athletes and only 426 clubs. Turkish judo should develop appropriate formulas and effective methods for the future of Turkish judo as indicated for small countries like Slovenia and Kosovo by Gutierrez-Garcia et al. (2018). The successes of young judo athletes stem from private coaches who find talented athletes via talent identifications. 


\section{CONCLUSIONS}

Turkish judo started to gain a place on the podium at international level in the 1990s and continued having a place on the podium in the World and European Championships so far despite a significant decrease in medal number. With the economic and scientific developments in judo and its popularity in Turkey, its future seems to be better with local athletes.

\section{KAYNAKLAR}

French Judo Federation (2020) https://www.ffjudo.com/ retrieved on $2^{\text {nd }}$ of May 2020

Guiterrez-Garcia, C., Santos, L., Montero-Carretero, C., Escobar-Molina, R. (2018). Éxitos del judo español ai el internacional: una perspectiva histórica. Revista de Artes Marciales Asiaticas, 13.

IJF (2019). Official website of International Judo Federation www.ijf.org retrieved on $5^{\text {th }}$ of November 2019.

Japan Judo Federation (2020) http://www.judo.or.jp/ retrieved on $2^{\text {nd }}$ of May 2020

Little N.G. (1991) Physical performance attributes of Junior and Senior women, Juvenile, Junior and Senior men judokas. J.Sports Med.Phys. Fitness, 31, 510-520

Morley, B., Thomas, D. (2005). An investigation of home advantage and other factors affecting outcomes in English one day cricket matches, Journal of Sports Sciences, 23, 261-268

Russian Judo Federation (2020) https://www.judo.ru/ retrieved on $2^{\text {nd }}$ of May 2020

Sato, S. (2013). The sportification of judo: global convergence and evolution. Journal of Global History, 8(2), 299-317.

TJF (2019) Official website of Turkish Judo Federation www.judo.gov.tr retrieved on $5^{\text {th }}$ of November 2019. 